\title{
Guideline values and human risk assessment for the presence of anti-inflammatory drugs remaining in drinking water after lab scale treatment
}

\author{
Mariana Castello Novo Pais ${ }^{* *}$, Elizabeth de Souza Nascimento ${ }^{2}$
}

${ }^{1}$ Graduate Program in Toxicology and Toxicological Analysis, Faculty of Pharmaceutical Sciences, University of São Paulo, São Paulo, SP, Brazil, ${ }^{2}$ Department of Clinical and Toxicological Analysis, Faculty of Pharmaceutical Sciences, University of São Paulo, São Paulo, SP, Brazil

\begin{abstract}
This study aimed to determine whether the anti-inflammatory drugs that are most commonly consumed in Brazil, including diclofenac, ketoprofen, naproxen, indomethacin, ibuprofen and acetaminophen, are present in drinking water and to derive guideline values to characterize the human risk. These pharmaceuticals were quantified in surface waters by LC-MS/MS with solid phase extraction, both before and after conventional treatment on a laboratory scale, using a jar test assay. The methods used to quantify these drugs showed good results: the chromatographic analysis obtained correlation coefficients between 0.9952 and 0.9991 , with limits of quantification of $0.5 \mathrm{ng} \cdot \mathrm{mL}^{-1}-50 \mathrm{ng} \cdot \mathrm{mL}^{-1}$ and precision standard deviations $(0.08-2.08)$. Only ketoprofen and ibuprofen were not completely removed through the jar test. Environmental samples were collected and handled by the same method; the values obtained for ketoprofen and ibuprofen after treatment were 18.67 - $19.65 \mathrm{ng} . \mathrm{L}^{-1}( \pm 17 \%)$ and $166.70-244.73$ ng.L $\mathrm{L}^{-1}$ $( \pm 14 \%)$, respectively. Human risk was assessed by comparing the guideline values for each compound to the concentrations obtained in the environmental samples, considering the toxicological backgrounds, following WHO (2011) method. The results suggest that the concentrations of ketoprofen and ibuprofen found in drinking water do not pose a risk to human health, even with chronic consumption.
\end{abstract}

Keywords: Emerging contaminant. LC-MS/MS. Human risk assessment. Pharmaceuticals in drinking water.

\section{INTRODUCTION}

Until the 1970s, the worldwide concern with water quality was mainly limited to its microbiological aspects. The interest of the scientific community and researchers in evaluating the presence of xenobiotics or emerging contaminants in different environments, such as the aquatic environment, led to the creation of environmental protection agencies such as the USEPA (United States Environmental Protection Agency) in 1970. Since then, many studies have been published about the presence and possible toxicity of drugs and their transformation products in the environment (Ternes, 2001; Raimundo, 2007; Kumar, Chang, Xagoraraki, 2010; Richardson,

\footnotetext{
*Correspondence: Programa de Graduação de Toxicologia e Análises Toxicológicas. Faculdade de Ciências Farmacêuticas, Universidade de São Paulo, 05508-900 São Paulo - SP, Brasil. E-mail: mary.pais@gmail.com
}

Ternes, 2011; Richardson, 2012; Stuart et al., 2012; Leung et al., 2013; Cai et al., 2015).

In 2008, Brazil was ranked first among Latin American countries and $50^{\text {th }}$ in the world in terms of the excessive use of medications (Souza, Silva, Neto, 2008). Such consumption and production may lead to the shedding of pharmaceuticals in wastewater, either as a result of human metabolism or by industrial spill. Pharmaceuticals and personal care products are the groups that are most frequently found in surface and drinking waters (Stumpf et al., 1999; Richardon, 2012; Cai et al 2015). The detection of these pharmaceuticals in drinking water raises considerable public concern, especially when human-based guideline values are not available (Schriks et al., 2010).

Such contaminations are not recent events; the first findings on the occurrence of drug residues in an aquatic environment date to 1965 and were related to drugs and 
substances that could interfere with the endocrine system. In 1976, Garrison, Pope and Allen used extractive methods and chromatographic analysis to report on the presence of other contaminants in waste water treatment plants in the United States.

New technologies allowed for the development of more sensitive, accurate and precise methods that can identify and quantify substances at concentrations as low as $\mathrm{ng} / \mathrm{L}$.

Even at low concentrations, the residue of biologically active drugs can have serious effects on aquatic biota, which, when they are not removed in sewage treatment, may result in health problems for most susceptible species because they can reach drinking water used by humans or animals (Melo et al., 2009; Cai et al., 2015; Villanueva et al., 2014) Anti-inflammatory drugs are one of drugs most frequently found in the environment. Such contamination can cause several toxic effects ranging from gastrointestinal problems to kidney damage, particularly within sensitive populations.

Issues that are pertinent to this type of contamination should be investigated. Guideline values for contaminants must be established, and long-term studies must be performed to analyze their possible chronic effects (Ghiselli, 2006; Richardson, Ternes, 2011).

Therefore, this paper aims to contribute to the evaluation of the conventional process of water treatment in Brazil by determining the degree of retention of antiinflammatory painkiller drugs and deriving guideline values to characterize the human risk.

\section{MATERIAL AND METHODS}

\section{Material}

The drugs acetaminophen, ketoprofen, diclofenac, ibuprofen, indomethacin and naproxen, were purchased from Sigma Aldrich Brazil (batch numbers: 099K0127V; BCBD6676V; BCBD6672V; 122K0676V; BCBC9386V; $078 \mathrm{~K} 1629)$ with purities ranging from 98.5 to $100 \%$.

Reagents, glassware and consumables: Glass fiber filters (GF/F $07 \mu \mathrm{m})$; C18 chromatographic column (Phenomenex - Endcapping $125 \times 3 \mathrm{~mm}$ ); automatic pipettes (10-40 $\mu \mathrm{L}$; 40-200 $\mu \mathrm{L})$; flasks $(10,25,100$ and $1000 \mathrm{ml}$ ); Beakers; Isolute C18 cartridge (Sep-pak ${ }^{\circledR}$ Vac 6cc - 500 mg- Waters ${ }^{\circledR}$ batch: 027536242A); Methanol (HPLC - Carlo Erba); ammonium acetate (mass spectrometric grade - Carlo Erba); Acetonitrile (HPLC - Carlo Erba); Acetone (p.a. - Merck), acetic acid (p.a. Merck), formic acid (Merck - HPLC), sulfuric acid (p.a. - Carlo Erba); hydrochloric acid (p.a. - Carlo Erba); C18 cartridge (Sep-pak ${ }^{\circledR}$ Vac 3cc - 500 mg, Waters $®$ batch: 027536242 nd); Sodium sulfate (p.a - Merck), sodium formate (High-Performance Liquid Chromatography (HPLC) or mass spectrometric (MS)); septum vial cap and septum compatible with HPLC Agilent ${ }^{\circledR}$; filter unit (0.22) PTFE Liquid Chromatography - Tendem mass spectrometry (LC/MS-MS); disposable Falcon tube $(5 \mathrm{~mL})$, test tube $(10,100$ and $1000 \mathrm{~mL})$, Pasteur pipettes; purification system Milli Q - Plus ${ }^{\circledR}$ Millipore, Millipore filter ${ }^{\circledR}$, regular detergent, commercial humic acid (SigmaAldrich).

Equipments: high-performance liquid chromatograph coupled with a mass spectrometer (Applied Biosystems ${ }^{\circledR}$ - API2000/MS/MS System); analytical balance (Denver Instrument ${ }^{\circledR}$ APX60); DR/2010 Spectrophotometer - Hach Company (Serial No.: 000500018060 ) and 2100N turbidimeter - Hach company.

\section{Methods}

Pharmaceuticals in the environmental samples were quantified by LC/MS-MS after solid phase extraction (SPE). After quantification, the samples were subjected to jar testing, which mimics the steps of water treatment, to evaluate the amount of contaminants removed from the treated water.

\section{Chromatographic method validation}

To validate the chromatographic method, solutions with increasing concentrations of drugs $(0.5$ - $500 \mathrm{ng}$ $\left.\mathrm{mL}^{-1}\right)$ were prepared to construct the calibration curve and determine the linearity, precision and accuracy of the method. The mobile phase consisted of Phase A (methanol) and Phase B (ammonium acetate $1 \mathrm{mM}$ ) in a concentration gradient ranging from $45-80 \%$ of $\mathrm{A}$ and $20-55 \%$ of $\mathrm{B}$, an injection volume of $20 \mu \mathrm{L}$, a column temperature of 122 ${ }^{\circ} \mathrm{F}$, and a pressure of 150 bar. Electrospray ionization (ESI) in positive mode was used for all drugs except for ibuprofen, which showed better results in negative mode.

\section{Solid Phase Extraction (SPE)}

The SPE concentration of the drugs was based on EPA method 1694, using a C18 cartridge. This method enhanced the samples concentrations by approximately 300 times (EPA, 2007).

\section{Jar Test method}

Standardization of the jar test was performed using samples that had been prepared in the laboratory. Known concentrations of the analytes of interest (ranging from 
35 to $150 \mathrm{ng} / \mathrm{L}$ ) were added to six jars (five jars with known concentrations and one control, in triplicate) with a capacity of 2 liters each, and their removal was assessed. Each jar was subjected to all steps of conventional water treatment: oxidation, coagulation, flocculation and disinfection with the possibility of $\mathrm{pH}$, temperature, coagulant and chlorine adjustments throughout the process. All the jar tests were carried out with humic acid aqueous solution $\left(20 \mathrm{mg} \mathrm{L}^{-1}\right)$, which is the main component of organic matter that is present in natural fresh water (Ishiwatari, 1969). The following operating parameters were optimized: oxidant concentration $(1-10 \mathrm{ppm} \mathrm{Cl})$, pre-oxidation time (5-30 $\mathrm{min}$ ), coagulant concentration (10-100 $\mathrm{mg} \mathrm{L}^{-1}$ of $\mathrm{FeSO}_{4}$ ) and optimum coagulation $\mathrm{pH}$ (3-8). The maximum allowable concentration of residual chlorine in drinking water $\left(2 \mathrm{mg} . \mathrm{L}^{-1}\right)$ was also considered.

\section{Analysis of the samples}

The samples were collected at Guarapiranga dam and at the University of São Paulo Olympic streak (São Paulo, Brazil) in December 2012. The first one is located at Alto Tietê in the southwest of São Paulo metropolitan region and is used as source for drinking water after treatment. The second one is located in the University of São Paulo, in the west region of the São Paulo city and is only used for recreation.

Water samples were collected in white and opaque plastic bottles (4-10 L) that had previously been cleaned with regular detergent and running water; the bottles had screw caps and were stored in a place with temperature control (approximately $20^{\circ} \mathrm{C}$ ), for 24 hours until solid phase extraction and jar tests were performed. The parameters of color, turbidity and $\mathrm{pH}$ were evaluated before extraction and chromatographic analysis. After the extraction process by SPE using 1 liter of each sample, the samples were re-suspended in $1 \mathrm{ml}$ of methanol; $300 \mu \mathrm{L}$ of this solution was aliquoted and increased to a volume of $1 \mathrm{~mL}$ with water and formic acid ( $\mathrm{pH} 4)$. Drug removal from water was evaluated in two spiked samples, before and after treatment by chromatographic analysis.

\section{Quantitative pharmaceuticals risk assessment}

Once the analytical phase was concluded, the quantitative pharmaceuticals risk assessment (QPhRA) was calculated as follows: (1) Hazard identification, (2) Exposure assessment, (3) Dose-response relationship, and (4) Risk characterization (Kumar, Chang, Xagoraraki, 2010).

Hazard identification was supported by literature review; exposure assessment was based on an analysis of the surface water after the conventional treatment.
The dose-response relationship was based on the most restrictive and relevant NOAEL (No-observed adverse effect level) found in the literature. The risk characterization was given by Hazard Quotient calculation (formula 2) that is the division product of Exposure Dose by Guideline value, according to the US EPA, 2011.

FORMULA 1 - The guideline value was found using formula 1, (WHO, 2011):

$$
\mathrm{GV}=\frac{(\mathrm{TDI} \times \mathrm{bw} \times \mathrm{P})}{\mathrm{C}}
$$

where: $\mathrm{GV}=$ Guideline Value $\left(\mathrm{mg} \mathrm{L}^{-1}\right.$ per day $)$; $\mathrm{bw}=$ body weight $(70 \mathrm{~kg}) ; \mathrm{P}=$ fraction of the TDI allocated to drinking water (10-20\%, usually); $\mathrm{C}=$ daily drinkingwater consumption $\left(2 \mathrm{~L} \mathrm{day}^{-1}\right)$; TDI $=$ Tolerable daily intake ( $\mathrm{mg} \mathrm{kg}^{-1}$ per day)

The guideline value is based on the multiplication of the Tolerable Daily Intake ( $m g$ per $\mathrm{kg} \mathrm{d}^{-1}$ ) (TDI) by the Body Weight (BW) and the fraction of the TDI allocated to drinking water $(\mathrm{P})$, divided by the chronic consumption (C). The TDI was calculated based on the most restrictive NOAEL, as found in literature, allocated to the factors of uncertainties that are applicable to each study.

FORMULA 2 - Hazard Quotient (HQ)' EPA, 2011.

$$
\mathrm{HQ}=\frac{\mathrm{ED}}{\mathrm{GV}}
$$

where: HQ = Hazard Quotient; ED = Exposure Dose $\left(\mathrm{mg} \mathrm{L}^{-1}\right) ; \mathrm{GV}=$ Guideline Value $\left(\mathrm{mg} \mathrm{L}^{-1}\right)$

According to US EPA, 2011: If HQ > 1.0, then harmful effects cannot be ruled out; if $H Q=1.0$, contaminant alone is not likely to cause risk; and if $\mathrm{HQ}<$ 1.0 , harmful effects are not likely.

\section{RESULTS AND DISCUSSION}

\section{Chromatographic method}

The chromatographic method showed adequate linearity, precision, accuracy and limits of detection and quantification that are adequate to quantify the analytes in question. In all of the analyses, a weighting factor of $1 / x$ for homoscedastic results, with smaller variance, was used. The limit of detection and quantification of the compounds ranged from $0.50 \mu \mathrm{g} \mathrm{L}^{-1}$ to $50 \mu \mathrm{g} \mathrm{L}^{-1}$, based on injections of decreasing amounts to evaluate the height of the peak and baseline, as presented in Table I. For all drugs a negative control (blank) was evaluated to guarantee the reliability of the method. 
The chromatogram obtained for all drugs, using the selected method, is shown in Figure 1.

\section{Jar test standardization and removal evaluation}

The evaluation of turbidity, color, and absorption at $\lambda$ $254 \mathrm{~nm}$ showed that significant reductions and/or reductions below the values set out in Brazilian legislation were obtained only after all processing steps were done, using the following conditions: pre-oxidation with $1 \mathrm{ppm} \mathrm{Cl}$ (as $\mathrm{NaCIO}$ ) for $10 \mathrm{~min}, 23 \mathrm{mg} . \mathrm{L}^{-1}$ of coagulant, and coagulation $\mathrm{pH}$ optimum between 5-6. In these conditions, the jar test process produced a water sample with a $\mathrm{pH} 6.0$, with a color beneath $1 \mathrm{uT}$ and a chlorine residual of $0.65 \mathrm{mg} \mathrm{L}^{-1}$, thus demonstrating that the concentrations of the added analytes were sufficient to ensure the reliability of the process, according to Brazilian decree 2914/2011. (Brasil, 2011).

The process of compound removal was shown to be highly capable of removing most of the analyzed compounds. Acetaminophen had high removal rates but still remained in some samples of treated water. The ketoprofen showed very low or no removal in alignment with what was found in the literature; ibuprofen showed great removal variation, as shown in Table I (Stumpf et al., 1999; Vieno et al., 2007).

\section{Solid phase extraction}

All analytes, except ibuprofen, showed the same recovery profile in the two homogeneous matrices: distilled water and water with humic acid. Acetaminophen had a recovery of approximately $20 \pm 2,5 \%$, but diclofenac showed a high recovery of $100 \pm 7,8 \%$. Ketoprofen also showed high recovery (approximately 99\%), as did naproxen (103.4\%) and indomethacin $(90.3 \%)$, with deviations below $10 \%$. Ibuprofen showed a wide variation in the first evaluated controls in both the distilled water matrix and the distilled water with humic acid. This analysis was repeated three times more with strict control of $\mathrm{pH}$ and luminosity, which resulted in an average recovery of $48 \pm 9.3 \%(58 \%, 47.5 \%, 39.5 \%)$.

The solid phase extraction efficiency is considering at the end of the experiments (removal evaluation) in order to obtain the final real concentration.

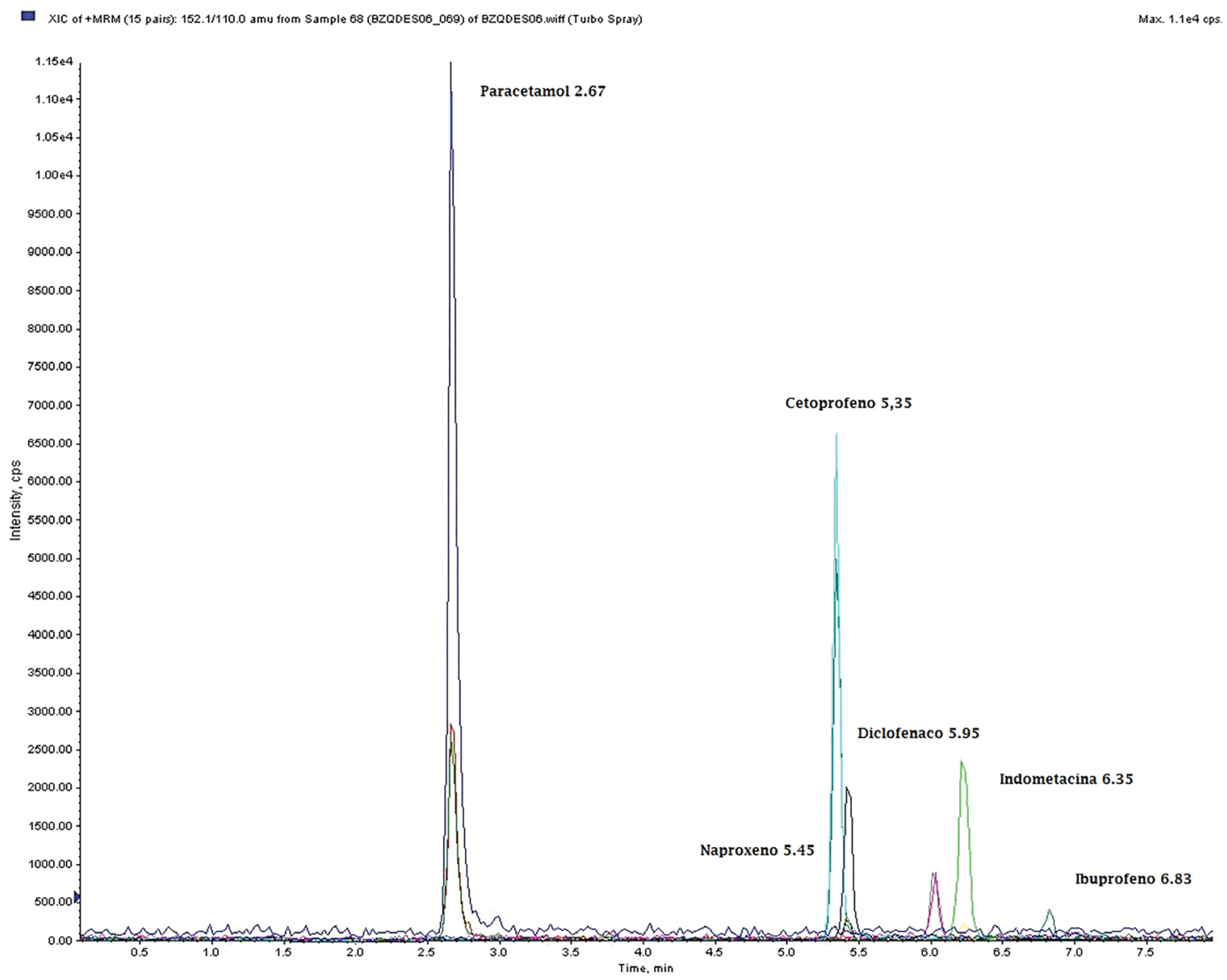

FIGURE 1 - Validation of the method: Chromatogram of drugs: acetaminophen, diclofenac, naproxen, ketoprofen, indomethacin and ibuprofen. 
Guideline values and human risk assessment for the presence of anti-inflammatory drugs remaining in drinking water

TABLE I - Percentage of removal of the evaluated compounds analyzed (in triplicates with $\mathrm{SD}<5 \%$ between them). Comparison of the peak areas before and after conventional treatment

\begin{tabular}{|c|c|c|c|c|}
\hline Pharmaceuticals & Jar Sample & $\begin{array}{c}\text { Concentration before } \\
\text { treatment }\left(\mathrm{ng} \mathrm{m}^{-1}\right)\end{array}$ & $\begin{array}{l}\text { Concentration after } \\
\text { treatment }\left(\mathrm{ng} \mathrm{mL}^{-1}\right)\end{array}$ & Removal \% \\
\hline \multirow{5}{*}{ Acetaminophen } & Sample 1 & 1650 & 14.1 & 99.14 \\
\hline & Sample 2 & 2920 & 242.3 & 91.72 \\
\hline & Sample 3 & 1500 & $<\mathrm{LOD}$ & 100.00 \\
\hline & Sample 4 & 2210 & 8.7 & 99.60 \\
\hline & Sample 5 & 1510 & $<\mathrm{LOD}$ & 100.00 \\
\hline \multirow{5}{*}{ Diclofenac } & Sample 1 & 2140 & $<\mathrm{LOD}$ & 100.00 \\
\hline & Sample 2 & 2990 & $<\mathrm{LOD}$ & 100.00 \\
\hline & Sample 3 & 2460 & $<\mathrm{LOD}$ & 100.00 \\
\hline & Sample 4 & 3290 & $<\mathrm{LOD}$ & 100.00 \\
\hline & Sample 5 & 3290 & $<\mathrm{LOD}$ & 100.00 \\
\hline \multirow{5}{*}{ Ketoprofen } & Sample 1 & 2110 & 2150 & $\mathbf{0}$ \\
\hline & Sample 2 & 4320 & 4730 & $\mathbf{0}$ \\
\hline & Sample 3 & 3360 & 2890 & 13.88 \\
\hline & Sample 4 & 1460 & 1510 & $\mathbf{0}$ \\
\hline & Sample 5 & 1900 & 1890 & 3.63 \\
\hline \multirow{5}{*}{ Naproxen } & Sample 1 & 3220 & $<\mathrm{LOD}$ & 100.00 \\
\hline & Sample 2 & 1980 & $<\mathrm{LOD}$ & 100.00 \\
\hline & Sample 3 & 1700 & $<\mathrm{LOD}$ & 100.00 \\
\hline & Sample 4 & 2850 & 3.74 & 99.88 \\
\hline & Sample 5 & 1470 & $<\mathrm{LOD}$ & 100.00 \\
\hline \multirow{5}{*}{ Indomethacin } & Sample 1 & 1910 & 2.82 & 99.87 \\
\hline & Sample 2 & 2240 & 3.32 & 99.87 \\
\hline & Sample 3 & 1320 & 2.37 & 99.85 \\
\hline & Sample 4 & 815 & 3.92 & 99.59 \\
\hline & Sample 5 & 3220 & 5.78 & 99.84 \\
\hline \multirow{5}{*}{ Ibuprofen } & Sample 1 & 5940 & 3560 & 40.14 \\
\hline & Sample 2 & 2830 & 1660 & 41.20 \\
\hline & Sample 3 & 2370 & 884 & 62.76 \\
\hline & Sample 4 & 1700 & 1500 & 11.74 \\
\hline & Sample 5 & 7070 & 1610 & 77.20 \\
\hline
\end{tabular}

< LOD: Value below the limit of detection of the analytical method

\section{Removal evaluation of the compounds in the environmental samples}

Water from the Olympic streak showed $\mathrm{pH} 9.0,4.38$ uT of turbidity and apparent color $52 \mathrm{PtCo} \mathrm{L}^{-1}$. Water from Guarapiranga showed $\mathrm{pH}$ approximately $6.0,10.7 \mathrm{uT}$ of turbidity and apparent color of $70 \mathrm{PtCo} \mathrm{L}^{-1}$. Both $\mathrm{pH}$ values are in accordance with the regular $\mathrm{pH}$ value for superficial water, according to Brazilian legislation CONAMA $\mathrm{n}^{0}$ 357 (Brasil, 2005).
Part of the samples (1 liter) was subjected to SPE to assess the actual concentration of each drug in the water in a triplicate analysis. This extraction method was validated in a similar manner as that previously performed, and samples were taken for chromatographic analysis. Table II shows the results of the SPE for the actual samples.

The water collected from the USP Olympic streak shows only $8 \mathrm{ng} / \mathrm{L}$ diclofenac, but in the water collected from Guarapiranga, all evaluated compounds were found, except acetaminophen, which was not detected in any of 
TABLE II - The concentrations of analytes obtained after SPE (300x concentrated) and analytes concentration in environmental samples $(n=3)$, considering the SPE concentration and recovery factor

\begin{tabular}{|c|c|c|c|c|c|c|c|}
\hline \multirow{2}{*}{ Drugs } & \multicolumn{4}{|c|}{$\begin{array}{l}\text { Mean concentration after SPE * } \\
\left(\text { ng.mL } L^{-1}\right)\end{array}$} & \multirow{2}{*}{$\begin{array}{l}\text { Efficiency } \\
\text { of SPE \% }\end{array}$} & \multicolumn{2}{|c|}{$\begin{array}{c}\text { Final (real) Concentration } \\
\left(\text { ng. } L^{-1}\right)\end{array}$} \\
\hline & USP & (SD) & Guarapiranga & (SD) & & USP & Guarapiranga \\
\hline Acetaminophen & $<\mathrm{LOD}$ & & $<\mathrm{LOD}$ & & $16-20$ & $<\mathrm{LOD}$ & $<\mathrm{LOD}$ \\
\hline Diclofenac & 2.27 & $(11 \%)$ & 8.62 & $(19 \%)$ & $95-100$ & $7.57-7.96$ & $28.73-30.25$ \\
\hline Ketoprofen & $<\mathrm{LOD}$ & & 5.60 & $(17 \%)$ & $90-100$ & $<\mathrm{LOD}$ & $18.67-19.65$ \\
\hline Naproxen & $<\mathrm{LOD}$ & & 3.30 & $(7.5 \%)$ & $95-100$ & $<\mathrm{LOD}$ & $11.00-11.58$ \\
\hline Indomethacin & $<\mathrm{LOD}$ & & 10.70 & $(2.4 \%)$ & $75-97$ & $<\mathrm{LOD}$ & $36.77-47.56$ \\
\hline Ibuprofen & $<\mathrm{LOD}$ & & 29.00 & $(14.4 \%)$ & $39.5-58$ & $<\mathrm{LOD}$ & $166.70-244.73$ \\
\hline
\end{tabular}

<LOD: Value below the detection limit of the method; SD: Standard Deviation. All samples were analyzed in triplicate with standard deviations $<20 \%$.

the samples (Table III). According to Xagoraraki et al. (2008), acetaminophen may be degraded and transformed by free chlorine. The rate of this degradation is affected by $\mathrm{pH}$ and chlorine/acetaminophen molar ratio. The highest degradation rates were observed at $\mathrm{pH} 9.0$, and the lowest degradation rates were observed at $\mathrm{pH}$ 6.0. In both cases, acetaminophen may be converted into the toxic byproduct, 1,4- benzoquinone.

In addition to the SPE procedures, the jar test was performed using an actual sample spiked with the evaluated drugs. Analytes were added at concentrations ranging from $35-150 \mathrm{ng} / \mathrm{mL}$. The samples were analyzed in triplicate, with standard deviations that ranged up to $20 \%$.

Table III shows that except for ibuprofen and ketoprofen, most of the compounds were degraded with the traditional method of treating water, following the same trend of the samples produced in the laboratory with humic acid and as reported by Cai et al. (2015). Diclofenac, indomethacin and naproxen are present in the sample from Guarapiranga; they are almost entirely removed in the water treatment station after the chlorination step.

Ketoprofen and ibuprofen, which were present in Guarapiranga water, were still present in the treated water at ng. $\mathrm{mL}^{-1}$ concentrations. A Quantitative Pharmaceutical Risk Assessment (QPhRA) was carried out for these two compounds.

\section{Quantitative Pharmaceuticals Risk Assessment (QPhRA)}

Human risk assessment of the compounds that were present in the aquatic environment and those that were not removed by water treatment (ibuprofen and ketoprofen) are discussed.
The concentrations of ibuprofen (166.70 to $244.73 \mathrm{ng} \mathrm{L}^{-1}$ ) and ketoprofen (18.67 to $19.65 \mathrm{ng} \mathrm{L}^{-1}$ ) that remained in the treated water were used to assess the risk, though these data are not adequate to characterize the entire water treated by conventional methods.

Although these drugs were present in low concentrations, it is important to consider the duration of the exposure and the sensitive population. With chronic exposure, anti-inflammatory drugs can induce kidney damage and gastrointestinal disturbances, as well as dyspnea, nausea, vomiting, irritation and ulcer, as describe in some toxicological reviews: HSDB, 2014; ECHA, 2008 and EMA, 1995. Based on these toxicological review studies of ketoprofen and ibuprofen and considering the most restrictive toxicological values found in the literature (Tables IV and V), it was possible to determine the tolerable daily intake to find a threshold value (guideline value) to evaluate the exposure risk, according to Formula 1 , previously presented in this article.

The guideline value for ibuprofen exposure (Table IV), is calculated from Formula 1, where the TDI is 0.40 $\mathrm{mg} \mathrm{kg}{ }^{-1}$ per day, $\mathrm{BW}$ is $70 \mathrm{~kg}$, the $\mathrm{P}$ is $20 \%$ and $\mathrm{C}$ is 2 liters. per day. The result was a guideline value of $2.8 \mathrm{mg} \mathrm{L}^{-1}$ per day.

The risk for ibuprofen was estimated by dividing $244.73 \times 10^{-6} \mathrm{mg} \mathrm{L}^{-1}$, the maximum concentration found in treated water, by the established guideline value of 2.8 $\mathrm{mg} \mathrm{L}^{-1}$; according to formula 2 . The obtained HQ value was $<1.0$.

The guideline value of $0.14 \mathrm{mg} \mathrm{L}^{-1} / \mathrm{d}$ for ketoprofen exposure (table V) is calculated from Formula 1, assuming a TDI of $0.02 \mathrm{mg} \mathrm{kg}^{-1} / \mathrm{d}$, a BW of $70 \mathrm{~kg}$, P of $20 \%$ and C 2 liters per day (WHO, 2011).

The risk for ketoprofen was estimated by dividing the maximum concentration found in treated water 
Guideline values and human risk assessment for the presence of anti-inflammatory drugs remaining in drinking water

TABLE III - Mean values of concentration of analytes added before and after the jar test procedure (two samples of each compartment with known concentration) and removal percentage of each analyte in samples of USP Olympic Streak and Guarapiranga Dam

\begin{tabular}{|c|c|c|c|c|c|c|c|}
\hline \multicolumn{4}{|c|}{ Olympic streak (ng.mL $\left.{ }^{-1}\right)$} & \multicolumn{4}{|c|}{ Guarapiranga Dam (ng.mL $\left.{ }^{-1}\right)$} \\
\hline & & Sample 1 & Sample 2 & & & Sample 1 & Sample 2 \\
\hline \multirow{3}{*}{ Acetaminophen } & Before & 41.5 & 17.5 & & Before & 34.9 & 53.9 \\
\hline & After & $<\mathrm{LOD}$ & $<\mathrm{LOD}$ & Acetaminophen & After & $<\mathrm{LOD}$ & $<\mathrm{LOD}$ \\
\hline & Removal & $100 \%$ & $100 \%$ & & Removal & $100 \%$ & $100 \%$ \\
\hline \multirow{3}{*}{ Diclofenac } & Before & 93 & 48.8 & & Before & 81.1 & 157 \\
\hline & After & $<\mathrm{LOD}$ & $<\mathrm{LOD}$ & Diclofenac & After & $<\mathrm{LOD}$ & $<$ LOD \\
\hline & Removal & $100 \%$ & $100 \%$ & & Removal & $100 \%$ & $100 \%$ \\
\hline \multirow{3}{*}{ Ketoprofen } & Before & 63.7 & 36.9 & & Before & 65.23 & 91.07 \\
\hline & After & 54.1 & 43.2 & Ketoprofen & After & 90 & 118 \\
\hline & Removal & $15 \%$ & $0 \%$ & & Removal & $0 \%$ & $0 \%$ \\
\hline \multirow{3}{*}{ Naproxen } & Before & 65.4 & 34.7 & & Before & 59.3 & 98.1 \\
\hline & After & $<\mathrm{LOD}$ & $<\mathrm{LOD}$ & Naproxen & After & $<\mathrm{LOD}$ & $<\mathrm{LOD}$ \\
\hline & Removal & $100 \%$ & $100 \%$ & & Removal & $100 \%$ & $100 \%$ \\
\hline \multirow{3}{*}{ Indomethacin } & Before & 54.9 & 25.6 & & Before & 51.47 & 88.67 \\
\hline & After & $<\mathrm{LOD}$ & $<\mathrm{LOD}$ & Indomethacin & After & $<$ LOD & $<\mathrm{LOD}$ \\
\hline & Removal & $100 \%$ & $100 \%$ & & Removal & $100 \%$ & $100 \%$ \\
\hline \multirow{3}{*}{ Ibuprofen } & Before & 57.66 & 50.17 & & Antes & 82.7 & 85.5 \\
\hline & After & 37.3 & 50.9 & Ibuprofen & Depois & 93.8 & 90.23 \\
\hline & Removal & $35 \%$ & $0 \%$ & & Removal & $0 \%$ & $0 \%$ \\
\hline
\end{tabular}

$<$ LOD: below the detection limit of the method

(19.65 x $\left.10^{-6} \mathrm{mg} \mathrm{L}^{-1}\right)$, by the established guideline value of $0.14 \mathrm{mg} \mathrm{L}^{-1}$ (Formula 2). The HQ value obtained was $<1.0$.

According to the guidelines and hazard quotients discussed above, it is clear that the concentrations of ibuprofen and ketoprofen found in treated water are below the exposure limit set for both.

\section{CONCLUSION}

The validation parameters of the chromatographic method used showed good linearity, accuracy and precision as well as an acceptable limit of detection and quantification for analyzing samples that contain diclofenac, ketoprofen, naproxen, indomethacin, ibuprofen and acetaminophen. The extraction method in solid phase showed linear values, low standard deviations and high precision for all samples, which made it a reliable extraction technique to focus on the analytes of interest. The removal test using the jar test values show the linear removal of the compounds in samples produced in the laboratory and in environmental samples. It is important to state that the experiment was done in a lab scale and the removal of the compounds from water may be overestimated once in a real scale there are a lot of other compounds and it is not possible to control chemical reaction for example.

Acetaminophen was not detected in the analyzed environmental samples, and spiked samples showed complete removal after the jar test. According to Xagoraraki et al. 2008, acetaminophen may be degraded by free chlorine, depending on the water $\mathrm{pH}$ and acetaminophen molar ratio, and it can be converted into the toxic byproduct 1,4-benzoquinone. Indomethacin and naproxen were detected only in water from Guarapiranga, whereas diclofenac was detected in samples from Guarapiranga and the Olympic streak. However, diclofenac showed high percentage of removal by the jar test after chlorination; therefore, it is unlikely to reach treated water.

Ketoprofen and ibuprofen peaked in water from Guarapiranga and had low or no percentage removal after treatment via jar test; thus, these two compounds are present in the treated water, as also reported by Cai et al. (2015). The removal methods of these compounds suggested by Melo et al. (2009) - ozonation and photoFenton - are expensive and is not part of the conventional 
TABLE IV - Determination of the reference dose of ibuprofen (base value for no carcinogenic substances)

\begin{tabular}{ll}
\hline Determination of the reference dose of ibuprofen \\
\hline NOAEL & $\begin{array}{l}\text { Based on the most restrictive } \\
\text { NOAEL found in toxicity studies } \\
\text { available, of } 40 \mathrm{mg} / \mathrm{kg} / \mathrm{bw} / \mathrm{day} \text { for } \\
\text { one year (ECHA, 2008). }\end{array}$ \\
\hline Point of departure (PD) & $40 \mathrm{mg} / \mathrm{kg}-\mathrm{d}$ \\
\hline Uncertainty factors & $\begin{array}{l}10 \text { to animal-human } \\
\text { extrapolation; } \\
10 \text { intraspecies variability; }\end{array}$ \\
\hline $\begin{array}{l}\text { Uncertainty factor final } \\
\text { (UF): }\end{array}$ & 100 \\
\hline $\begin{array}{l}\text { Reference dose TDI } \\
\text { (based on PD/UF) }\end{array}$ & \begin{tabular}{l}
$0.40 \mathrm{mg} / \mathrm{kg} / \mathrm{d}$ \\
\hline
\end{tabular} \\
$\begin{array}{l}\text { Statistical analysis revealed higher } \\
\text { kidney weights for the animals } \\
\text { receiving } 100 \mathrm{mg} / \mathrm{kg} / \mathrm{day}, \text { which } \\
\text { was considered to be related to } \\
\text { dosing with the test substance. } \\
\text { Examination of the kidneys } \\
\text { revealed areas of cortical pitting } \\
\text { in } 9 / 10 \mathrm{receiving} 100 \mathrm{mg} / \mathrm{kg} / \mathrm{day} \text {. }\end{array}$ \\
\hline
\end{tabular}

TABLE V - Determination of the Reference Dose of ketoprofen (base value for not carcinogenic substances)

\begin{tabular}{ll}
\hline Determination of the reference dose of ketoprofen \\
\hline NOAEL & $\begin{array}{l}\text { Based on the most restrictive } \\
\text { NOAEL found in literature: dose } \\
\text { of } 2 \mathrm{mg} / \mathrm{kg} / \text { day derived from } \\
\text { the results of the teratogenicity } \\
\text { toxicity study in rabbits (EMA, } \\
1995) .\end{array}$ \\
\hline Point of departure (PD) & $2 \mathrm{mg} / \mathrm{kg}$-d \\
\hline Uncertainty factors & $\begin{array}{l}10 \text { animal to human; } \\
10 \text { sensitive population }\end{array}$ \\
\hline $\begin{array}{l}\text { Uncertainty factor final } \\
\text { (UF): }\end{array}$ & 100 \\
\hline $\begin{array}{l}\text { Reference dose (based } \\
\text { on PD/UF) }\end{array}$ & \begin{tabular}{l}
$0.02 \mathrm{mg} / \mathrm{kg} / \mathrm{d}$ \\
\hline $\begin{array}{l}\text { Critical effects } \\
\text { (endpoint) }\end{array}$
\end{tabular} \\
\hline
\end{tabular}

method of treatment performed in the state of São Paulo.

Based on the guideline value and hazard quotient, the results suggest human risk only in concentrations higher than $2.8 \mathrm{mg} \mathrm{L}^{-1}$ and $0.14 \mathrm{mg} \mathrm{L}^{-1}$ for ibuprofen and ketoprofen, respectively; therefore, no significant risk to humans is indicated at the concentrations found. Other authors, such as Schwab et al. (2005) and Webb et al. (2003), also reported no risk or a low possibility of health risk due to exposure to these pharmaceuticals. In this study, risk assessment based on the mixture of chemicals was not reported.

Although indomethacin, diclofenac and naproxen do not show peaks in the chromatograms after water treatment, it does not necessarily mean that they are completely eliminated. Reaction with the oxidation products may be added to the water generated by-products, which are known as "disinfection byproducts" and are often more toxic than their precursors.

Because some of these compounds, such as acetaminophen and diclofenac, react with the oxidizing agent used in water treatment plants, disinfection products may be produced, which are reportedly more toxic than their precursors (Bedner, Maccrehan, 2006; Xangoraraki et al., 2008). Therefore, it is recommended to qualitatively and quantitatively evaluate the formation of these products after the chlorination process to assess human risk from consuming this water.

\section{ACKNOWLEDGEMENTS}

CAPES. FCF-USP. Chromanalysis ${ }^{\circledR}$ Analitical Laboratory.

\section{REFERENCES}

Bedner M, Maccrehan WA. Transformation of acetaminophen by chlorination produces the toxicants 1,4-Benzoquinone and N-Acetyl-p-benzoquinone imine. Environ Sci Technol Libr. 2006;40(2):516-22.

Brasil. Ministério da Saúde. Portaria n.2914 de 12 de dezembro de 2011. [cited 2014 Nov 15]. Available from: <http://e-legis. bvs.br/leisref/public/showAct.php?id=15132\&word $>$.

Brasil. Conselho Nacional do Meio Ambiente. CONAMA. Resolução ${ }^{0} 357$ de 17 de março de 2005. [cited 2016 October]. Available from: <://www.mma.gov.br/port/conama/res/res05/ res35705.pdf $>$.

Cai MQ, Wang R, Feng L, Zhang LQ. Determination of selected pharmaceuticals in tap water and drinking water treatment plant by high-performance liquid chromatography-triple quadrupole mass spectrometer in Beijing. China. Environ Sci Pollut Res Int. 2015;22(3):1854-67. 
European Medicines Agency. EMA. Veterinary Medicines Evaluation Unit. Ketoprofen, 1995. [cited 2017 September]. Available from: http://www.ema.europa.eu/docs/en GB/document_library/Maximum_Residue_Limits_Report/2009/11/WC500014541.pdf.

European Chemicals Agency. ECHA. Ibuprofen, 2008. [cited 2017 September]. Available from: https://echa.europa.eu/it/ registration-dossier/-/registered-dossier/1270/7/6/1.

Environmental Protection Agency (USA). EPA. Method 1694. 2007. [cited 2016 October]. Available from: https:// www.epa.gov/sites/production/files/2015-10/documents/ method_1694_2007.pdf.

Environmental Protection Agency (USA). EPA. Risk Characterization, 2011. [cited 2016 May]. Available from: http://www.epa.ohio.gov/portals/30/Brownfield_Conference/ docs/Presentations/3-Risk\%20characterization.pdf.

Garrison AW, Pope JD, Allen FR. Identification and analysis of organic pollutants in water. Ann Arbor, Mich.: Ann Arbor Science Publishers; 1976; p.517.

Ghiselli G. Potable water quality in the Campinas Region: Occurrence and Determination of Endocrine Disruptors (EDs) and Pharmaceuticals and Personal Care Produts (PPCPs) 2006. 190 p. (Tese Doutorado em Química). Instituto de Química. Universidade Estadual de Campinas, Campinas.

Hazardous Substances Data Bank. HSDB. Ibuprofen. [cited 2014 Feb. 20]. Available from: http://toxnet.nlm.nih.gov/cgibin/sis/search2/f?./temp/ TrPACo:3.

Ishiwatari R. Fractionation and characterization of humic acid from lake sediment. Geochem J. 1969;2:175-184.

Kumar A, Chang B, Xagoraraki I. Human health risk assessment of pharmaceuticals in water: issues and challenges ahead. Int $\mathrm{J}$ Environ Res Public Health. 2010;7(11):3929-3953.

Leung HV, Jin L, Wei S, Tsui M., Zhou B, Jiao L, Cheung PC, Chun YK, Murphy MB, Lam PK. Pharmaceuticals in tap water: human health assessment and proposed monitoring framework in China. Environ Health Perspect. 2013;121(7):839-46.

Melo SAS, Trovó AG, Bautitz IR, Nogueira RFP. Degradação de fármacos residuais por processos oxidativos avançados (Degradation of waste pharmaceuticals by advanced oxidation processes.). Quim Nova. 2009;32(1):188-197.
Raimundo CCM. Ocorrência de interferentes endócrinos e produtos farmacêuticos nas águas superficiais da bacia do rio Atibaia. Tese de Doutorado, Universidade de Campinas, Brasil, 2007.

Richardson SD. Environmental mass spectrometry: emerging contaminants and current issues (2010 Review). ACS Monogr. 2012;84(2):747-778.

Richardson SD, Ternes TA. Water analysis: emerging contaminants and current issues. 2011 review. Analytical Chemistry. ACS Monogr. 2011;83(12):4614-4648.

Schriks M, Heringa, MB, Van der Kooi MM, De Voogt P, Van Wezer AP. Toxicological relevance of emerging contaminants for drinking water quality. Water Res. 2010;44(2):461-479.

Schwab BW, Hayes EP, Fiori JM, Mastrocco FJ, Roden NM, Cragin D, Meyerhoff RD, D'Aco VJ, Anderson PD. Human pharmaceuticals in US surface waters: A human health risk assessment. Regul Toxicol Pharmacol. 2005;42(3):296-312.

Sousa HWO; Silva JL, Neto MS. Importância do profissional farmacêutico no combate à automedicação no Brasil. Rev Eletr Farm. 2008;5(1):67-72.

Stuart MA, Lapworth DA, Crane E, Hart A. Review of risk from potential emerging contaminants in UK groundwater. Sci Total Environ. 2012;416:1-21.

Stumpf M, Ternes TA, Wilken R, Rodrigues SV, Baumann W. Polar drug residues in sewage and natural waters in the state of Rio de Janeiro, Brazil. Sci Total Environ. 1999;225(1-2):135141.

Ternes T. Pharmaceuticals and personal care products in the environment: Scientific and regulatory issues TrAC. Trends Anal Chem. 2001;20:419.

Vieno NM, Harkki H, Tuhkanen T, Kronberg L. Occurrence of pharmaceuticals in river water and their elimination in a pilot-scale drinking water treatment plant. Environ Sci Technol. 2007;41(14):5077-5084.

Villanueva CM, Kogevinas M, Cordier S, Templeton MR, Vermeulen R, Nuckols JR, Nieuwenhuijsen MJ, Levallois P. Assessing exposure and health consequences of chemicals in drinking water: current state of knowledge and research needs. Environ Health Perspect. 2014;122(3):213-221. 
Webb S, Ternes T, Gibert M, Olejniczak K. Indirect human exposure to pharmaceuticals via drinking water. Toxicol Lett. 2003;142(3):157-167.

World Health Organization. WHO. Guidelines for drinkingwater quality. 4th ed. Geneva: World Health Organization; 2011.
Xagoraraki I, Hullmanm R, Wenlu S, Li H, Voice TJ. Effect of $\mathrm{PH}$ on degradation of 19 acetaminophen and production of 1,4-benzoquinone in water chlorination. AQUA. 2008;57(6):381-390.

Received for publication on $09^{\text {th }}$ June 2017 Accepted for publication on $27^{\text {th }}$ September 2017 